\title{
Nursing perceptions of medication administration practices, reasons for errors and reporting of errors in a tertiary care hospital, Bangalore
}

\author{
Meenakshi Mahesh ${ }^{1}$, Hajira Saba I. ${ }^{2}$, Arun Gopi ${ }^{3}$
}

${ }^{1}$ III Year MBBS, ${ }^{2}$ Assistant Professor, ${ }^{3}$ Bio-statistician, Department of Community Medicine, Vydehi Institute of Medical Sciences and Research Centre, Bangalore, Karnataka, India

Received: 02 December 2015

Accepted: 08 January 2016

\author{
*Correspondence: \\ Meenakshi Mahesh, \\ E-mail: meenakshimahesh123@gmail.com
}

Copyright: () the author(s), publisher and licensee Medip Academy. This is an open-access article distributed under the terms of the Creative Commons Attribution Non-Commercial License, which permits unrestricted non-commercial use, distribution, and reproduction in any medium, provided the original work is properly cited.

\begin{abstract}
Background: Nurses administer drugs directly to patients and they are the last link in the safe medication administration chain. Due to the increased acuity of patients they serve, and decrease in the resources available to ensure safe practice, there are more chances of errors to occur. The study was thus taken up to describe their perspectives towards medication administration practices, sources and reporting of errors.

Methods: Study was conducted on nursing staff of Vydehi Hospital, Bangalore, India. The study was cross sectional type of study which has taken one month duration to complete. By simple random sampling, 199 nurses were selected and interviewed. They were administered a semi structured questionnaire after obtaining oral consent and assuring complete anonymity. The data was analyzed using Chi-square, Annova and principal component analysis, SPSS version 21.

Results: Among the nurses, 97\% always checked the patient's file for medication details before administration, $45.7 \%$ never prepared medications for more than 2 patients at a time and $78.4 \%$ always checked the expiry date before administering the drug. $83.9 \%$ nurses always practice sterile conditions for administering intramuscular and intravenous medicines.

Conclusions: The common causes of errors were mislabelled drugs and names/labels of medicines which look alike. $66.3 \%$ of nurses always reported the errors. There was a significant association between the years of experience and the lack of cross checking with another nurse before administering of heparin and insulin and checking composition of medicines.
\end{abstract}

Keywords: Nursing perceptions, Medication safety, Reasons for errors, Reporting errors

\section{INTRODUCTION}

Patient safety practices have been defined as "those that reduce the risk of adverse events related to exposure to medical care across a range of diagnoses or conditions". ${ }^{1}$ Many patient safety practices, such as use of simulators, bar coding, computerized physician order entry, and crew resource management, have been considered as possible strategies to avoid patient safety errors and improve health care processes; ongoing research has been exploring these areas, but there remains innumerable opportunities for further research. ${ }^{1}$
Patient safety is a vital component of quality care. Nurses administer drugs directly to patients and they are the last link in the safe medication administration chain. Due to the increased acuity of patients they serve, and decrease in the resources available to ensure safe practice, there are more chances of errors to occur. ${ }^{2}$ Although patient safety is a shared responsibility amongst doctors, nurses, caregivers, the government etc., nursing has clearly been concerned with defining and measuring quality long before the current National and State-level emphasis on quality improvement. Florence Nightingale analyzed mortality data among British troops in 1855 and 
accomplished significant reduction in mortality through organizational and hygienic practices. ${ }^{3}$ Execution of medical orders is an important part of the healing process and patient care. It is also the main component of nursing performance and has a prominent role in patient safety. ${ }^{4-7}$ Medication errors can lead to adverse outcomes such as increased mortality, increased duration of hospitalization, and increased medical expenses. ${ }^{8,9}$

The purpose of this study was to:

- To describe the nurses' perspectives towards medication administration practices, sources of errors and reporting of errors.

- To describe the relationship between current practice of drug administration and work experience.

\section{METHODS}

- Study area: Vydehi Hospital, Bangalore, India

- Study population: Nursing staff working at various wards of Vydehi Hospital

- $\quad$ Study duration: 1 month (Aug-Sept 2015)

- Study type: Cross Sectional Study

- Sample size calculation: Assuming the least estimated difference of means between the different medication practices as 0.2 , a sample size of around 150 was calculated at a significance level of $5 \%$.

- Materials and methods: Total nursing staff working in Critical Care, Emergency department, Intensive Care Units and General Wards were 540 out of which, by simple random sampling, 199 nurses were selected and interviewed in a tertiary care hospital, by administering a semi structured questionnaire ${ }^{10}$ (Figure1) after obtaining oral consent and assuring complete anonymity.

The data collected was grouped into various categories for statistical purposes. The medical practices were categorized into 2 - Processing practices (4 components) and Administering practices (6 components). All the departments were grouped into 6 broad categories-critical care, emergency, medicine, mother and child health, surgery and others. For Principal Component analysis, the items in the questionnaire were divided into 4 subscales- dosage care, right patient, preparing/ carrying medication and reporting of errors.

Analysis was done by using SPSS Version 21. ANOVA and Chi-Square tests were used at $95 \%$ confidence interval. Inferences were drawn and the conclusions were derived.

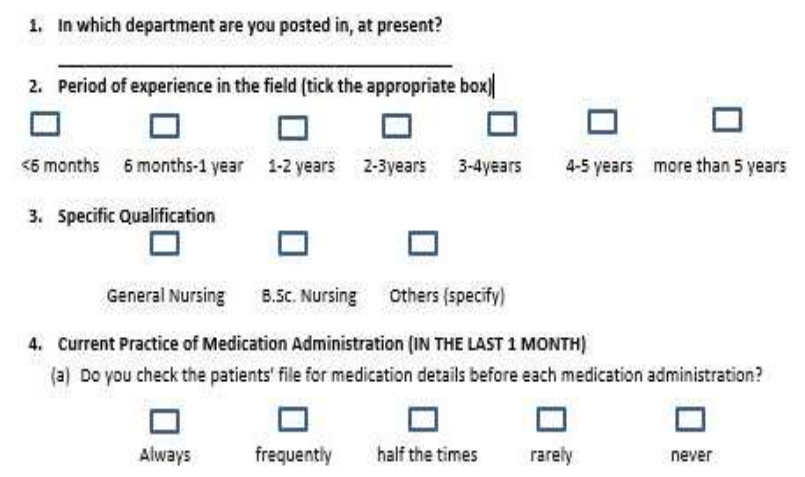

(b) Do you prepare and carry medications for more than 2 patients with you, at a time?

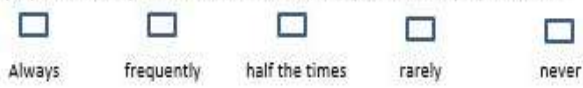

(c) Do you bring the medication sheet/file with you while drug administration?

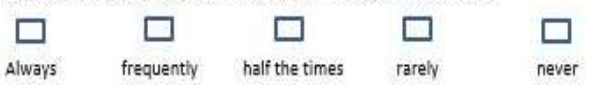

(d) Do you label the syringes and medication bags with the patient name and bed/ room number?

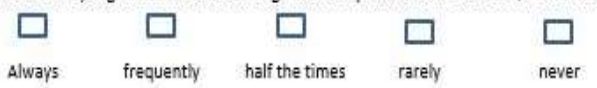

(e) Do you administer medication prepared by another nurse?

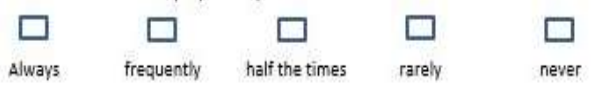

(f) Do you double check with another nurse while administering drugs like heparin and insulin?

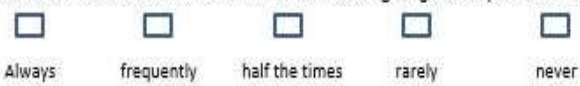

(g) Do you check the composition of the drugs before administering it?

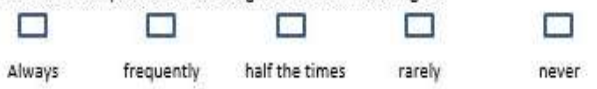

(hi) Do you check the expiry date of the drugs before administration?

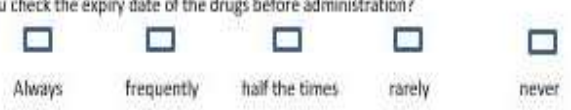

(i) Do you maintain the starage prerequisites for the drugs?

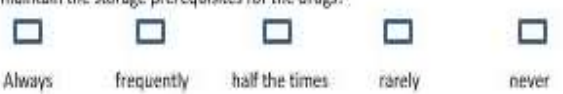

(i) Do you practice the sterile conditions far Intravenaus and Intramuscular injectable medicines?

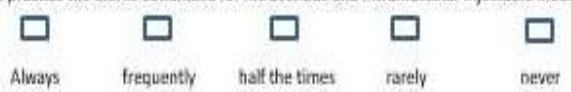

5. Causes of Errors(mark any 6)

\begin{tabular}{|c|c|c|}
\hline 1. Computer entry & 9. Distractions while drug administration & \\
\hline 2. Pharmatyeriof & 10. Miscalculation of dosage & \\
\hline 3. Efror in checking the medication sheet & 11. Pracedure/ policy nat followed & \\
\hline 4. Legibility while prescribing & 12. Prescription filled incarrectly & \\
\hline 5. Incorrect of der while prestribing & 13. Mislabeled drugs & \\
\hline 6. Confusing arder/ instructions & 14. Names of medicines laok alike & \\
\hline 7. Misunderstaod verbal order & 15. Labels of medicines look alike & \\
\hline B. Knowledge deficit & 16. Others, specily. & \\
\hline
\end{tabular}

6. Reporting of errors. I report medication errors using the Incident/ Accident.

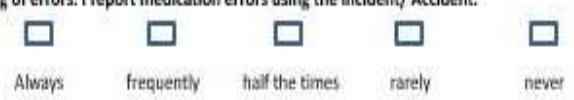

Figure 1: The semi structured questionnaire. 


\section{RESULTS}

$19.6 \%$ nurses were found to have an experience of below one year, $56.8 \%$ had 1 to 3 years and $23.6 \%$ had more than 3 years' experience. $48.7 \%$ of the nurses were general nursing graduates and $49.7 \%$ were B.Sc. Nursing graduates. Among the processing practices, 97\% nurses always checked the patient's file for medication details before medication administration and $89.9 \%$ always brought the medication sheet during drug administration. $79.9 \%$ nurses always double checked with another nurse before administering heparin and insulin and $60.8 \%$ always maintained storage prerequisites for the drugs (Table 1).

Table 1 : Distribution of study population according to the processing practices.

\begin{tabular}{|c|c|c|c|c|c|c|c|c|}
\hline & \multicolumn{2}{|c|}{$\begin{array}{l}\text { Checking patient's file } \\
\text { before each } \\
\text { administration }\end{array}$} & \multicolumn{2}{|c|}{$\begin{array}{l}\text { Bringing medication } \\
\text { sheet along while } \\
\text { administration }\end{array}$} & \multicolumn{2}{|c|}{$\begin{array}{l}\text { Double checking with } \\
\text { another nurse before } \\
\text { heparin/insulin } \\
\text { administration }\end{array}$} & \multicolumn{2}{|c|}{$\begin{array}{l}\text { Maintenance of storage } \\
\text { perquisites for drugs }\end{array}$} \\
\hline & Frequency & Percentage & Frequency & Percentage & Frequency & Percentage & Frequency & Percentage \\
\hline Always & 193 & 97 & 179 & 89.9 & 149 & 74.9 & 121 & 60.8 \\
\hline Frequently & 5 & 2.5 & 13 & 6.5 & 31 & 15.6 & 56 & 28.1 \\
\hline $\begin{array}{l}\text { Half the } \\
\text { times }\end{array}$ & 0 & 0 & 2 & 1 & 8 & 4 & 16 & 8 \\
\hline Rarely & 1 & 0.5 & 1 & 0.5 & 10 & 5 & 6 & 3 \\
\hline Never & 0 & 0 & 4 & 2 & 1 & 0.5 & 0 & 0 \\
\hline Total & 199 & 100 & 199 & 100 & 199 & 100 & 199 & 100 \\
\hline
\end{tabular}

Table 2: Distribution of study population according to the administering practices.

\begin{tabular}{|lllllll|} 
& \multicolumn{2}{l}{$\begin{array}{l}\text { Prepare/carry medications for } \\
\text { more than 2 }\end{array}$} & patients at a time & \multicolumn{2}{l}{$\begin{array}{l}\text { Labeling syringes and } \\
\text { medication bags with } \\
\text { patient's name/bed no. }\end{array}$} & \multicolumn{2}{l|}{$\begin{array}{l}\text { Administering medicines } \\
\text { prepared by another nurse }\end{array}$} \\
& Frequency & Percentage & Frequency & Percentage & Frequency & Percentage \\
\hline Always & 27 & 13.6 & 161 & 80.9 & 12 & 6 \\
\hline Frequently & 16 & 8 & 16 & 8 & 10 & 5 \\
\hline Half the times & 14 & 7 & 14 & 7 & 9 & 4.5 \\
\hline Rarely & 51 & 25.6 & 5 & 2.5 & 51 & 25.6 \\
\hline Never & 91 & 45.8 & 3 & 1.5 & 117 & 58.8 \\
\hline Total & 199 & 100 & 199 & 100 & 199 & 100 \\
\hline
\end{tabular}

Table 3: Distribution of study population according to the administering practices.

\begin{tabular}{|c|c|c|c|c|c|c|}
\hline & \multicolumn{2}{|c|}{$\begin{array}{l}\text { Checking the composition of } \\
\text { medicines before } \\
\text { administration }\end{array}$} & \multicolumn{2}{|c|}{$\begin{array}{l}\text { Checking the expiry date of } \\
\text { medicines before } \\
\text { administration }\end{array}$} & \multicolumn{2}{|c|}{$\begin{array}{l}\text { Maintenance of sterile } \\
\text { conditions for I.V and I.M } \\
\text { injections }\end{array}$} \\
\hline & Frequency & Percentage & Frequency & Percentage & Frequency & Percentage \\
\hline Always & 156 & 78.4 & 182 & 91.5 & 167 & 83.9 \\
\hline Frequently & 32 & 16.1 & 16 & 8 & 27 & 13.6 \\
\hline Half the times & 8 & 4 & 0 & 0 & 4 & 2 \\
\hline Rarely & 3 & 1.5 & 0 & 0 & 1 & 0.5 \\
\hline Never & 0 & 0 & 1 & 0.5 & 0 & 0 \\
\hline Total & 199 & 100 & 199 & 100 & 199 & 100 \\
\hline
\end{tabular}


Table 4: Medication processing and administering practices in different departments.

\begin{tabular}{|c|c|c|c|c|c|c|}
\hline Department & \multicolumn{3}{|c|}{ Processing practices } & \multicolumn{3}{|c|}{ Administering practices } \\
\hline Overall(N)-199 & $\mathrm{N}$ & Mean (SD) & $P$ value & $\mathrm{N}$ & Mean (SD) & $P$ value \\
\hline Critical Care & 57 & $1.23(0.346)$ & \multirow{7}{*}{$<0.001$} & 57 & $1.38(0.352)$ & \multirow{7}{*}{$=0.001$} \\
\hline Emergency & 20 & $1.08(0.261)$ & & 20 & $1.51(0.609)$ & \\
\hline Medicine & 14 & $1.55(0.297)$ & & 14 & $1.78(0.499)$ & \\
\hline Mother and child health & 26 & $1.14(0.246)$ & & 26 & $1.44(0.294)$ & \\
\hline Surgery & 14 & $1.53(0.425)$ & & 14 & $1.82(0.542)$ & \\
\hline Others & 68 & $1.34(0.348)$ & & 68 & $1.42(0.416)$ & \\
\hline Total & \multicolumn{2}{|c|}{199} & & \multicolumn{2}{|c|}{199} & \\
\hline
\end{tabular}

Table 5: Association between experience and the components of current practice.

\begin{tabular}{|c|c|c|c|c|c|c|c|}
\hline \multirow{2}{*}{$\begin{array}{l}\text { Experience } \\
\text { (Years) }\end{array}$} & \multicolumn{5}{|c|}{ Heparin/Insulin Administration } & \multirow{2}{*}{ Total } & \multirow{2}{*}{ P value } \\
\hline & Always & Frequently & Half the times & Rarely & Never & & \\
\hline \multirow{2}{*}{$<1$} & 24 & 7 & 4 & 4 & 0 & 39 & \multirow{8}{*}{0.003} \\
\hline & $61.50 \%$ & $17.90 \%$ & $10.30 \%$ & $10.30 \%$ & $0.00 \%$ & $100.00 \%$ & \\
\hline \multirow{2}{*}{$1-3$} & 84 & 19 & 4 & 6 & 0 & 113 & \\
\hline & $74.30 \%$ & $16.80 \%$ & $3.50 \%$ & $5.30 \%$ & $0.00 \%$ & $100.00 \%$ & \\
\hline \multirow{2}{*}{$>3$} & 41 & 5 & 0 & 0 & 1 & 47 & \\
\hline & $87.20 \%$ & $10.60 \%$ & $0.00 \%$ & $0.00 \%$ & $2.10 \%$ & $100.00 \%$ & \\
\hline \multirow{3}{*}{ Total } & 149 & 31 & 8 & 10 & 1 & 199 & \\
\hline & $74.90 \%$ & $15.60 \%$ & $4.00 \%$ & $5.00 \%$ & $0.50 \%$ & $100.00 \%$ & \\
\hline & \multicolumn{6}{|c|}{ Checking the composition of medicines before administration } & \\
\hline \multirow{2}{*}{$<1$} & 26 & 7 & 4 & 2 & 0 & 39 & \multirow{8}{*}{0.001} \\
\hline & $66.70 \%$ & $17.90 \%$ & $10.30 \%$ & $5.10 \%$ & $0.00 \%$ & $100.00 \%$ & \\
\hline \multirow{2}{*}{$1-3$} & 88 & 20 & 4 & 1 & 0 & 113 & \\
\hline & $77.90 \%$ & $17.70 \%$ & $3.50 \%$ & $0.90 \%$ & $0.00 \%$ & $100.00 \%$ & \\
\hline \multirow{2}{*}{$>3$} & 42 & 5 & 0 & 0 & 0 & 47 & \\
\hline & $89.40 \%$ & $10.60 \%$ & $0.00 \%$ & $0.00 \%$ & $0.00 \%$ & $100.00 \%$ & \\
\hline \multirow{3}{*}{ Total } & 156 & 32 & 8 & 3 & 0 & 199 & \\
\hline & $78.40 \%$ & $16.10 \%$ & $4.00 \%$ & $1.50 \%$ & $0.00 \%$ & $100.00 \%$ & \\
\hline & \multicolumn{6}{|c|}{ Maintenance of sterile conditions for I.V and I.M drug administration } & \\
\hline \multirow{2}{*}{$<1$} & 29 & 7 & 2 & 1 & 0 & 39 & \multirow{8}{*}{0.003} \\
\hline & $74.40 \%$ & $17.90 \%$ & $5.10 \%$ & $2.60 \%$ & $0.00 \%$ & $100.00 \%$ & \\
\hline \multirow{2}{*}{$1-3$} & 94 & 17 & 2 & 0 & 0 & 113 & \\
\hline & $83.20 \%$ & $15.00 \%$ & $1.80 \%$ & $0.00 \%$ & $0.00 \%$ & $100.00 \%$ & \\
\hline \multirow{2}{*}{$>3$} & 44 & 3 & 0 & 0 & 0 & 47 & \\
\hline & $93.60 \%$ & $6.40 \%$ & $0.00 \%$ & $0.00 \%$ & $0.00 \%$ & $100.00 \%$ & \\
\hline \multirow{3}{*}{ Total } & 167 & 27 & 4 & 1 & 0 & 199 & \\
\hline & $83.90 \%$ & $13.60 \%$ & $2.00 \%$ & $0.50 \%$ & $0.00 \%$ & $100.00 \%$ & \\
\hline & Reporti & rors & & & & & \\
\hline \multirow{2}{*}{$<1$} & 24 & 7 & 2 & 5 & 1 & 39 & \multirow{8}{*}{0.174} \\
\hline & $61.50 \%$ & $17.90 \%$ & $5.10 \%$ & $12.80 \%$ & $2.60 \%$ & $100.00 \%$ & \\
\hline \multirow{2}{*}{$1-3$} & 71 & 26 & 2 & 10 & 4 & 113 & \\
\hline & $62.80 \%$ & $23.00 \%$ & $1.80 \%$ & $8.80 \%$ & $3.50 \%$ & $100.00 \%$ & \\
\hline \multirow{2}{*}{$>3$} & 37 & 2 & 2 & 5 & 1 & 47 & \\
\hline & $78.70 \%$ & $4.30 \%$ & $4.30 \%$ & $10.60 \%$ & $2.10 \%$ & $100.00 \%$ & \\
\hline \multirow{2}{*}{ Total } & 132 & 35 & 6 & 20 & 6 & 199 & \\
\hline & $66.30 \%$ & $17.60 \%$ & $3.00 \%$ & $10.10 \%$ & $3.00 \%$ & $100.00 \%$ & \\
\hline
\end{tabular}


Table 6: Results of principal component analysis and internal consistency.

\begin{tabular}{|c|c|c|}
\hline $\begin{array}{l}\text { Items for medication } \\
\text { questionnaire by sub-scale }\end{array}$ & $\begin{array}{l}\text { Factor } \\
\text { loading }\end{array}$ & $\begin{array}{l}\text { Cronbach } \\
\text { coefficient } \\
\text { alpha } \\
\text { (Standardized) }\end{array}$ \\
\hline \multicolumn{3}{|l|}{ Subscale 1: Dosage care } \\
\hline $\begin{array}{l}\text { Administering medicines } \\
\text { prepared by another nurse }\end{array}$ & 0.88 & \multirow{2}{*}{0.691} \\
\hline $\begin{array}{l}\text { Double checking } \\
\text { heparin/insulin doses }\end{array}$ & 0.52 & \\
\hline \multicolumn{3}{|l|}{ Subscale 2: Right patient } \\
\hline $\begin{array}{l}\text { Checking patient's file prior } \\
\text { to administering }\end{array}$ & 0.72 & \multirow{3}{*}{0.613} \\
\hline $\begin{array}{l}\text { Labelling of } \\
\text { syringes/medication bags } \\
\text { with patient details }\end{array}$ & 0.81 & \\
\hline $\begin{array}{l}\text { Bringing medication sheet } \\
\text { while administering }\end{array}$ & 0.55 & \\
\hline \multicolumn{3}{|c|}{ Subscale 3: Preparing/ carrying medication } \\
\hline $\begin{array}{l}\text { Prepare and carry } \\
\text { medications for more than } 2 \\
\text { patients at a time }\end{array}$ & 0.73 & 0.71 \\
\hline \multicolumn{3}{|c|}{ Subscale 4: Reporting of errors } \\
\hline $\begin{array}{l}\text { Are the errors being } \\
\text { reported }\end{array}$ & 0.81 & 0.51 \\
\hline
\end{tabular}

Among the Administering Practices - $45.7 \%$ nurses never prepared medications for more than 2 patients at a time. $80.9 \%$ always labeled the syringes and medication bag with the patient's name and bed number. 58.8\% never administered medications prepared by another nurse. (Table 2) $78.4 \%$ of nurses always checked the composition of the medication before administration. $91.5 \%$ always checked the expiry date before administering the drug and $83.9 \%$ always practice sterile conditions for administering intramuscular and intravenous medicines (Table 3).

66.3\% nurses always reported errors without fail (Figure 2 ). The most common perceptions regarding the causes of errors were found to be mislabeled drugs, names of medicines that looked alike, labels of medicines that looked alike, incorrect prescription, errors in computer entry and Pharmacy error.

A significant difference was observed in both processing and administering practices among nurses from varied departments (Table 4).

There was a significant association between the years of experience and certain practices such as, checking the composition of the medicine before administration, double checking with another nurse before administering heparin/ insulin, maintenance of storage prerequisites of drugs and maintenance of sterile conditions while administration of I.V or I.M drugs. There was no significant association between experience and reporting of errors (Table 5).

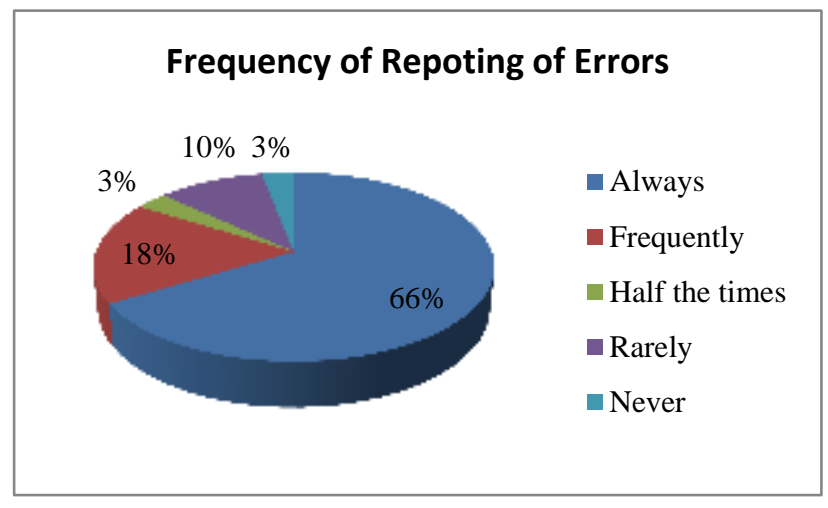

Figure 2: Distribution of study population according to reporting of errors.

\section{DISCUSSION}

This study was undertaken to identify the aspects of nursing care and medication administration that are most likely affecting the patient safety scenario. Among the Processing practices, checking the patients' file for medication administration was the most favorable and maintaining storage prerequisites for the drugs was least favorable. Almost all nurses checked the expiry date of drugs before administering, but not many checked the composition of the drugs.

In Lefrak's study (2002), insufficient communication with personnel, order of magnitude errors in numbers followed by multiple zeros or with fractional numbers, unreadable handwriting, distraction during preparation or administration of medications, availability of drugs with similar names, dosage assessment, and lack of knowledge were included as the causes of medication errors. Most of the causes correlated with the ones of the present study.

Similar to the previous studies, there was a difference in medication practices across various departments. These are likely explained by differences in the patient population and the types and number of medications used in particular departments. ${ }^{10}$ The severity of the disease and the criticality of the patients the department caters to may also have a bearing on the nursing practices. For instance an emergency care nurse maybe more tuned to a heavy patient load and commits lesser errors.

In the literature, age and years of practice were not correlated with medication errors (Osborne et al. 1999, Anderson 2003, Mayo \& Duncan 2004) or reporting of errors. ${ }^{10}$ Whereas, in the present study, some errors correlated with experience. Thus, relationships between sample's characteristics and medication errors should be studied in depth in future research studies. 
It is difficult to eliminate all medication errors. However, the role of nursing administrators in reducing and preventing these errors is vital. Although most medication errors can be minor and may not harm the patients, they need more supervision and planning. Reporting medication errors is an ethical duty to maximize the benefits of patient care. It can thus improve patient safety and health. Therefore, managers should have a positive attitude toward the reporting of medication errors by nurses. ${ }^{11}$ More continuous training programs for nurses will help to overcome the errors caused by lack of experience.

\section{ACKNOWLEDGEMENTS}

I thank the Chairperson, Principal and Medical Superintendent of Vydehi Institute of Medical Sciences for their constant support and advice. I extend my sincere gratitude to all the nurses of Vydehi Hospital for their complete cooperation and valuable time in filling the questionnaire. I thank my guide and statistician, without whom this paper would not be possible. My parents and friends have been the strongest support throughout this study.

Funding: No funding sources

Conflict of interest: None declared

Ethical approval: Not required

\section{REFERENCES}

1. Shojania KG, Duncan BW, McDonald KM et al, eds. Making health care safer: a critical analysis of patient safety practices. Evidence Report/Technology Assessment No. 43 (Prepared by the University of California at San FranciscoStanford Evidence-based Practice Center under Contract No. 290-97-0013). Rockville, MD: Agency for Healthcare Research and Quality; 2001. AHRQ Publication No. 01-E058, Summary.

2. Michelle Colleran Cook. Nurses' Six Rights for Safe Medication Administration. Available at http://www.massnurses.org/nursingresources/nursin g-practice/articles/six-rights. Accessed September 2015.

3. Mitchell PH. Defining patient safety and quality care. Hughes RG (ed). Patient safety and quality: an evidence-based handbook for nurses. 08-0043 ed. Rockville, MD: Agency for healthcare research and quality; 2008:1-5.

4. Cheraghi MA, Nikbakht NAR, Mohammad NE, Salari A, Ehsani KKSR. Medication errors among nurses in intensive care units (ICU). J Mazandaran Univ Med Sci. 2012;22(1):115-9.

5. Tang FI, Sheu SJ, Yu S, Wei IL, Chen CH. Nurses relate the contributing factors involved in medication errors. J Clin Nurs. 2007;16:447-55.

6. Marin HF. Improving patient safety with technology. Int J Med Inform. 2004;73:543-6.

7. Stratton KM, Blegen MA, Pepper G, Vaughn T. Reporting of medication errors by pediatric nurses. $\mathrm{J}$ Pediatr Nurs. 2004;19:385-92.

8. Mohammadnejad E, Hojjati H, Sharifnia SH, Ehsani SR. Amount and type of medication errors in nursing students in four Tehran. J Med Ethic Hist. 2009;3(1):60-9.

9. Mihailidis A, Krones L, Boger J. Assistive computing devices: a pilot study to explore nurses preference and needs. Comput Inform Nurs. 2006;24:328-36.

10. Armutlu M, Foley ML, Surette J, Belzile E, McCusker J. Survey of nursing perceptions of medication administration practices, perceived sources of errors and reporting behaviours. Health quarterly. 2008;11(3):58-65.

11. Cheragi MA, Manoocheri H, Mohammadnejad E, Ehsani SR. Types and causes of medication errors from nurse's viewpoint. Iranian J Nurs Midwifery Res. 2013;18(3):228-230.

Cite this article as: Mahesh M, Hajira SI, Gopi A. Nursing perceptions of medication administration practices, reasons for errors and reporting of errors in a tertiary care hospital, Bangalore. Int J Community Med Public Health 2016;3:459-64. 